Esta publicación cientifica en formato digital es continuidad de la revista impresa ISSN-Versión Impresa 0798-1406 / ISSN-Versión on line 2542-3185Depósito legal pp
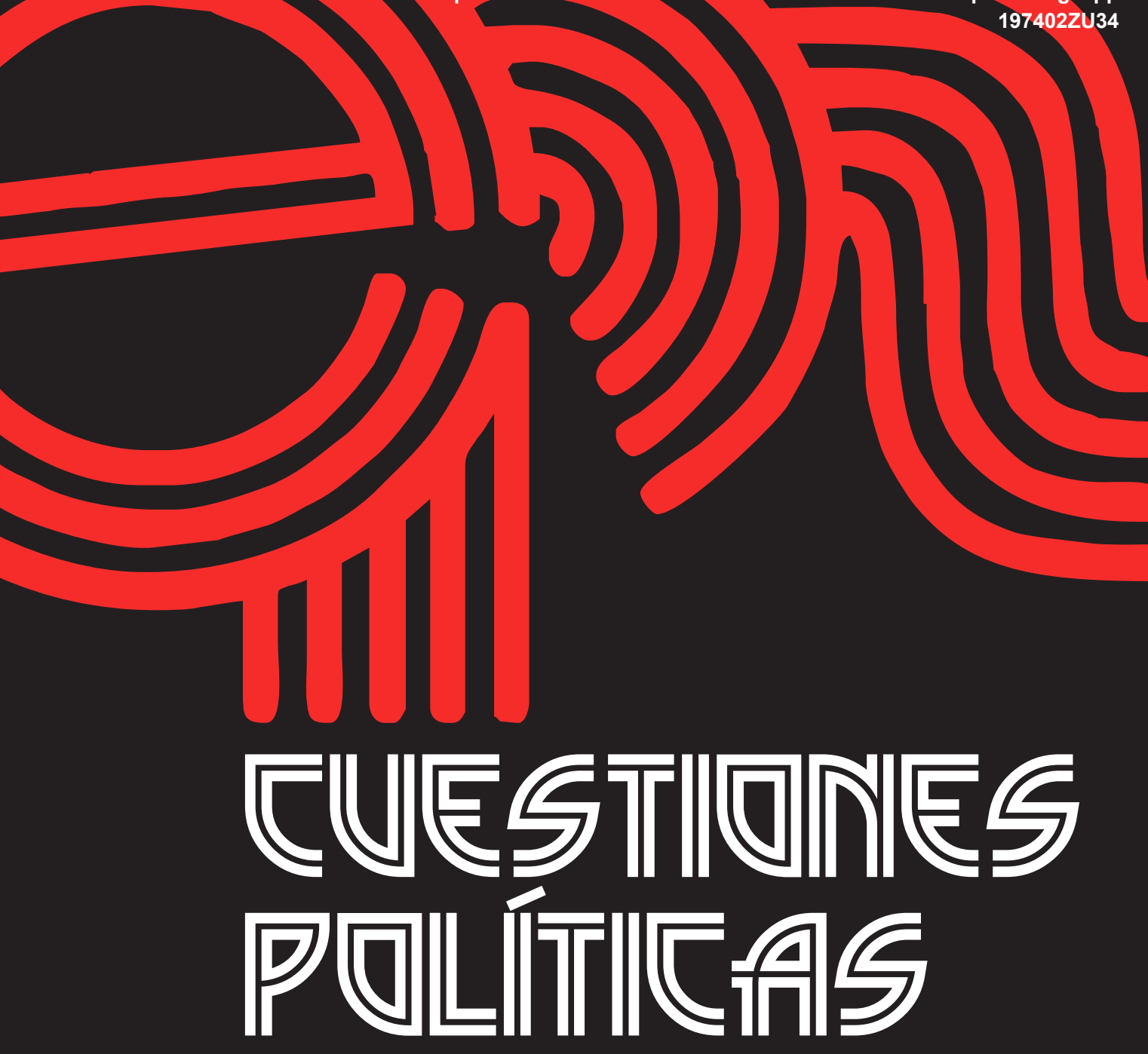

Instituto de Estudios Políticos y Derecho Público "Dr. Humberto J. La Roche" de la Facultad de Ciencias Jurídicas y Políticas de la Universidad del Zulia Maracaibo, Venezuela
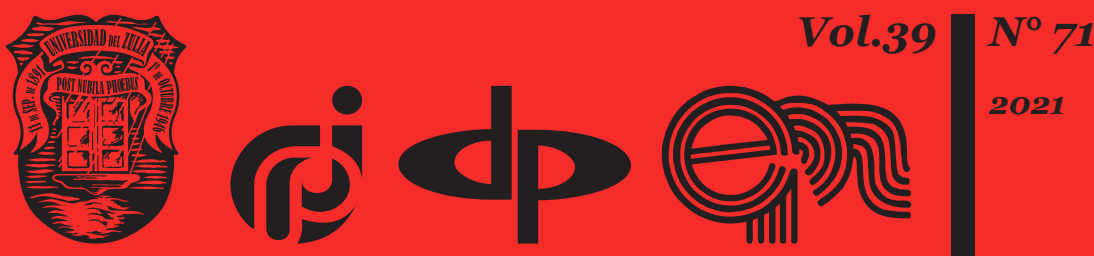


\title{
Guarantees within tax legal relations: challenges of the present day
}

\author{
DOI: https://doi.org/10.46398/cuestpol.3971.22
}

\author{
Yevhen Leheza * \\ Andrii Novytskyi ** \\ Alina Kravziuk *** \\ Nataliia Repekha **** \\ Artem Yefremov *****
}

\begin{abstract}
The purpose of the research is dedicated to modern challenges related to the implementation of legal guarantees within tax legal relationships. Legal guarantees within tax legal relations are the embodiment of the constitutional and legal guarantees of human and civil rights and, at the same time, act as an integrated intersectoral tool, covering both the administrative, financial and tax spheres respectively. The methodological basis of the article consisted of a set of general and special methods of scientific knowledge that, when applied, provide the opportunity to achieve the stated objective and ensure the scientific reliability and validity of the theoretical conclusions obtained. It is concluded that, to implement the potential to ensure taxpayers' choice of alternative methods of taxation, it is necessary to create conditions for commercial entities to perform the appropriate calculations and make the appropriate decisions. Entrepreneurs should receive government help in this through various electronic services.
\end{abstract}

Keywords: taxpayers; tax legal relationships; legal guarantees; electronic services; alternative tax systems.

* Professor, Doctor of Science in law, Professor at the Department of Administrative and Customs Law, University of Customs and Finance, Dnipro, Ukraine. ORCID ID: https://orcid.org/oooo-0001-91348499

** Andrii Novytskyi, Doctor of Science in Law, Professor, State Fiscal University of Ukraine. Ukraine. ORCID ID: https://orcid.org/oooo-0001-6860-9654

*** Alina Kravziuk, graduate student, State Fiscal University of Ukraine. Ukraine. ORCID ID: https:// orcid.org/oooo-0002-1735-5225

**** Nataliia Repekha, graduate student, State Fiscal University of Ukraine. Ukraine. ORCID ID: https:// orcid.org/o000-0002-5901-7259

***** Artem Yefremov, PhD in Science of Law, Head of the Main Directorate of the STS in Kharkiv region. Ukraine. ORCID ID: https://orcid.org/oooo-0001-7972-0323

Recibido el 03/10/2021 Aceptado el 23/11/2021 


\section{Garantías dentro de las relaciones legales tributarias: desafíos actuales}

\section{Resumen}

El propósito de la investigación está dedicado a los desafíos modernos relacionados con la implementación de garantías legales dentro de las relaciones legales tributarias. Las garantías legales dentro de las relaciones jurídicas tributarias son la encarnación de las garantías constitucionales y legales de los derechos humanos y civiles y, al mismo tiempo, actúan como una herramienta intersectorial integrada, que abarca tanto el ámbito administrativo como el financiero y tributario respectivamente. La base metodológica del artículo consistió en un conjunto de métodos generales y especiales de conocimiento científico que, al ser aplicados, brindan la oportunidad de lograr el objetivo planteado y asegurar la confiabilidad científica y validez de las conclusiones teóricas obtenidas. Se concluye que, con el fin de implementar el potencial de garantizar la elección de los contribuyentes de métodos alternativos de tributación, es necesario crear condiciones para que las entidades comerciales realicen los cálculos adecuados y tomen las decisiones adecuadas. Los emprendedores deberían recibir gubernamental ayuda en esto mediante diversos servicios electrónicos.

Palabras clave: contribuyentes; relaciones jurídicas tributarias; garantías legales; servicios electrónicos; sistemas tributarios alternativos.

\section{Introduction}

In recent years, scholars and practitioners, especially in the field of jurisprudence, are concerned about how effective is the procedure of guaranteeing human and civil rights by the Ukrainian state, and which model of the state is more able to guarantee for citizens their rights and freedoms? This necessitates the clarification of various approaches to the concept and possible classification of "guarantees of human and civil rights and freedoms with legal guarantees within tax legal relations taking a prominent role in these rights and freedoms. It is generally believed that guaranteeing legal protection and protection of human rights is a comprehensive function of the state.

Guarantees within tax legal relations are a sectoral embodiment of the system of constitutional guarantees of human rights and freedoms. The subject of regulation of tax law is presented as a set of financial and legal norms governing public relations arising in connection with 
the establishment, collection, change or abolition of taxes, fees, other mandatory payments to budgets of various levels and trust funds in form of monetary assets ensured by the coercive force of the state apparatus. Tax law is a system of financial and legal relations, which regulates the tax relations of state bodies and taxpayers to establish, change and collect a part of taxpayers' income to the budget, - says P.T. Gegha (Gegha, 2003). It is also worth recalling that according to Professor M.P. Kucheryavenko, the tax right is in a state of administrative law, or even belongs to it as an independant institution (Kucheryavenko, 2003). Thus, Legal guarantees within tax legal relations are the embodiment of constitutional and legal guarantees of human and civil rights and at the same time they act as an integrated intersectoral tool, which covers the administrative sphere as well as financial and tax spheres.

\section{Literature Review}

The legal term "guarantee" comes from the French "garantie", which means a surety, a condition that provides something. In modern encyclopedic literature, the concept of guarantee (from the French 'garantie' - security, surety) of human and civil rights and freedoms is understood as conditions, means, methods that ensure a full-range implementation and comprehensive protection of individual rights and freedoms. The concept of "guarantee" covers the whole set of objective and subjective factors aimed at the practical realization of rights and freedoms, to eliminate possible obstacles to their complete or proper implementation (Shemshuchenko, 1998).

From the standpoint of the theory of law and domestic constitutionalism, the issue of guarantees of human and civil rights and freedoms is a topic widely covered in scientific publications. The situation with the applied aspect of assessing the impact of guarantees precisely in the legal relationship of a tax nature is quite different.

When defining the concept of guarantee V. M. Kornukov wrote:

Everything that to any extent contributes to achievement of certain results or provides a certain condition can be regarded as a guarantee of the relevant activity or condition, because it promotes this activity, protects this condition, that is it guarantees them. The general concept of a guarantee is often quite conditional and, if the expression may be tolerated, mobile, because what in one case is a guarantee, in another case is not such (Kornukov, 1988: 410).

It should be noted that the concept of guarantees reflects the perfection of legislative technique and the variety of law language forms. In his work V. F. Pogorilko considers legal guarantees as the provision by the state of a formal (legal) generally binding nature of conditions necessary for everyone 
could be able to exercise his/her constitutional rights and freedoms. Legal guarantees are established by the state in the Constitution and norms of the current legislation. Their purpose is to provide real legal means for maximum exercising protection of rights and freedoms of citizens (Pogorilko, 1999).

When speaking about implementation of rights and freedoms of persons and citizens A.R. Yuzefir noted that within the limits of the whole (system) the purpose of guarantees consists in that they are called to provide such most possible and favorable situation for person's rights and freedoms (those written down in the Constitution and laws) could become the de facto position of each individual and citizen (Yuzefir, 2018).

O.F. Skakun believes that the guarantees of human and civil rights, freedoms and responsibilities are a system of social and economic, political, legal conditions, methods and means that ensure their actual implementation, protection and reliable protection. When it is not about guarantees, rights, freedoms and responsibilities of persons and citizens take the form of declarations of intent (Skakun, 2006).

Guarantees help to fix ways for achieving reality of rights and freedoms (the way guarantees unction) - provision, implementation, protection and defense of rights and freedoms.

The system of guarantees also includes such guarantees as social and political, social and economic (material), ideological, legal (lawful).

The role and significance of guarantees of individual rights and freedoms is determined by the fact that they are important factors in the economic, political, legal, cultural and other spheres of social life, which create conditions for real possibility to implement individual rights and freedoms. The system of guarantees of individual rights and freedoms is quite complex and extensive.

Economic guarantees of rights and freedoms constitute a separate important group of guarantees. Their significance is especially raised in the conditions of a market economy, under creating a material basis of life of the society. It should be noted that economic guarantees of human and civil rights and freedoms in Ukraine deserve a special attention. Let's consider how this concept is interpreted by modern scientists. V. F.Pogorilko states economic guarantees of rights and freedoms of citizens of Ukraine as: method of production; economic freedom of citizens and their associations in choosing forms of ownership and carrying out business activities; economic system of the society which should ensure a steady growth of productive forces based on recognition and protection of various forms of ownership of the means of production; socially-oriented market economy (Pogorilko, 2006). 
According to V.Y. Tatsiy and Y.M. Todyka economic and social guarantees include material conditions and social environment that ensure the free use of human rights and freedoms (Tatsiy et al, 1999).

Thus, an important task of the present day consists in the necessity to assess the current state and challenges of practical realization of guarantees within tax legal relations, as a special variety of economic guarantees of persons and citizens.

\section{Material and Methods}

The methodological basis of the article consists in a set of general and special methods of scientific knowledge which if applied give an opportunity to achieve the set goal and ensure the scientific reliability and validity of the obtained theoretical conclusions. The consistency and positivity of methodological application results is due to their complexity, which naturally led to the completeness, comprehensiveness and objectivity of the formulated scientific conclusions. The research was based on a systematic method, which contributed to a comprehensive and objective study of legal phenomena and categories in the process of their interaction. In particular, the systematic approach is used to determine the system of legal doctrines, define the place of guarantees within tax legal relations, establish a system of subjects of forming guarantees within tax legal relations, outline the system of principles of guarantees within tax legal relations. Based on taking into account such qualities of the system as component, integrativeness, the ratio of the whole and a part, functions and structure functional and structural analysis provided an in-depth study of such categories as "doctrine", "legal doctrine", "guarantees within tax legalrelations", etc.

\section{Results and Discussion}

Important challenges of today in the sphere of practical implementation of guarantees in tax legal relations of Ukraine include three interrelated elements. We are talking about the widespread use of international practice to guarantee taxpayers' choice of alternative ways of taxing their income, challenges of special territorial tax profiles and guarantees for their participants, the widespread use of "electronic legal relations" in tax administration (in Ukraine it is better known as "digitalization").

1. Guarantees for payers' choosing alternative methods of taxation. Economic (stimulating) function is one of the key functions of taxation, which ensures harmonization of interests of all participants of tax relations. By means of this function the state can encourage taxpayers to develop 
those areas and activities that meet the priorities of the national economy, stimulate the intensification of investment processes and rational use of resources etc. On the other hand, with the help of tax policy, the state can prevent development of areas it is not interested in.

Alternative taxation systems are a common tool for optimizing the tax burden on small businesses. Tax reform gives us an opportunity to talk more specifically about the special attitude to small businesses in this area. Small enterprises with regard to their payment of taxes have got a possibility of a certain choice, limited by the requirements of the tax legislation: taxpayer applies either the general tax profile or an alternative system. When the taxation system is properly selected business entities receive opportunities to optimize the burden of paying taxes and focus their efforts on other tasks.

Researching foreign countries' experience in legal regulation of taxation of small and medium-sized businesses have an opportunity to reveal the following specific features: according to the legislation of most developed countries small and medium-sized businesses are defined as a special subject of state regulation; the specifics of taxation of such payers consists in the possibility to apply privileges, choice of alternative taxation, simplified reporting and increase of investment activity of small and medium-sized businesses; alternative taxation systems have more incentive principles for businesses and efficiency of tax administration for these categories, and namely these principles include: the principle of certainty, the principle of sufficiency and elasticity of tax receipts, the principle of social justice and the principle of economic substantiation, as compared to the principles of the general taxation system (Anistratenko, 2017).

Alternative taxation systems are a certain manifestation of the society democratization. In their presence business entities (taxpayers) have the opportunity to independently choose tax conditions of management, i.e. they have the opportunity to actively influence this factor of the external environment, and this significantly increases the degree of their freedom in making business decisions. Therefore, the possibility of applying alternative taxation systems at the level of business entities should be considered as one of the reserves to improve the efficiency of their management.

In developed countries, alternative taxation systems are aimed at stimulating the development of certain sectors of the economy and prioritized forms of entrepreneurial activity. The systemic nature of these tax regulation instruments is manifested in the fact that in case of their application the structure of tax payments and tax objects are fundamentally changed.

The alternative nature of these systems in most countries that use such a regulator is determined by the following factors: 
- the same activity carried out by an economic agent may be taxed only under one taxation system - the ordinary (general) one or an alternative one.

- each of these systems is an alternative to the general taxation system, i.e. it limits the relevant list of taxes and fees that are mandatory. At that, the choice of one of these systems exempts the payer from paying a number of the most legally significant taxes and fees, which are provided by the general system.

- transition to one of these taxation systems (subject to the established restrictions) is largely conditioned by the decision of the taxpayer itself.

In the Tax Code of Ukraine, a separate chapter 1 of Section 14 "Special Tax Profiles" is devoted to the issues of simplified system of taxation, accounting and reporting. This chapter establishes legal principles for application of simplified taxation, accounting and reporting system, as well as for collection of a single tax. A simplified system of taxation, accounting and reporting is a special mechanism for collecting taxes and fees as well as for keeping records. A legal entity or a sole proprietor may independently choose a simplified taxation system if such an entity/natural person meets the requirements and is registered as a single tax payer according to the procedure (Law of Ukraine, 2010).

Today, there are four groups of single tax payers and a general taxation system for sole proprietors and limited liability companies. The first group is created for traders in the markets; the fourth group is for farmers. The general system, the second and the third groups are the most common in Ukraine. The first group of sole proprietors pays the single tax and the unified social tax (the UST), has a limit of UAH 1,002,000 of annual turnover, has the right to trade in the markets and provide household services to the population. Types of services are listed in paragraph 291.7 of the TCU. The second group of sole proprietors pays the fixed unified social tax and the single tax monthly, has a limit of UAH 5,004,000 of annual turnover. Proprietors of the second group have the right to engage in restaurant business, production and sale of goods, as well as in provision of services to the public and single tax payers. For example, for the IT-sector this taxation system is not always suitable. The third group of sole proprietors pays the UST and $5 \%$ of the income tax and has a limit of UAH 7,002,000 of annual turnover. This group is also suitable for legal entities and gives an opportunity to provide services without restrictions. The fourth group is created for agrarians and has its own registration conditions.

Thus, at first glance, the effectiveness of implementing the guarantee of taxpayers' choice of alternative methods of taxation is obvious - it is a simplified system of taxation. But it is not always right. Comparison 
of alternative taxation systems and the general taxation system gives an opportunity to conclude on the feasibility and necessity of such alternatives that stimulate activity of small businesses and, as a consequence, increase economic growth (Slatvinska, 2012). At the same time, in order to more or less accurately calculate the amount of taxes that will have to be paid in the case of choosing a particular taxation system it is necessary to know the estimated amounts of revenue and expenses, and this is not always possible. However, for typical cases, recommendations can be made based on the knowledge of typical economic indicators, even without accurate calculations. For a legal entity, the correct choice of a proper taxation system is a more difficult task than for a sole proprietor (a natural person). This can be done most accurately by comparing results of calculations of several alternatives using the respective estimated amounts of income and expenses.

Alternative taxation systems solve two extremely urgent problems:

- implementation of the regulatory function of taxation, in particular stimulating the growth of activities and efficient use of available resources, as well as stimulating effective employment of population and small business development as a basis for formation of an entrepreneurial initiative in the country;

- reduction of administrative pressure on business activities, which significantly reduces expenses of the state for administration of taxes as well as taxpayers' fees and the costs for preparation of reports, and it also reduces the risk of errors and application of penalties. This aspect, along with the reduction of the tax burden in many cases, is crucial for taxpayers in making a decision on the transition to this or that alternative system.

Thus, in order to implement the potential of guaranteeing taxpayers' choice of alternative methods of taxation it is necessary to create conditions for business entity's performing appropriate calculations and making appropriate decisions. Entrepreneurs should be helped in this by various electronic services (Halaburda et al., 2021).

2. Distribution of "electronic legal relations" in the sphere of tax administration. The modern Internet has become a universal means of communication, commerce, instant payments, a space for the realization of rights and interests of individuals, and the unimpeded access to the web environment is recognized as one of the universal human and civil rights. Formation of the doctrine of "electronic rights" or «digital rights» of individuals is going on. It is natural that such a situation requires legislator's close attention to the mechanisms of protection and defense of the rights, freedoms and interests of both individual Internet users and the society as a whole. Not least of all, this concerns the regulation of present day tax legal relations. 
Creation of an effective public and legal mechanism for legal regulation of public relations using the Internet-network is incomplete. Active development of the information society and digital economy, global processes of digital transformation in Ukraine and the world in general, form the tasks set out in the CMU Program of Activities on "the state in smartphones", "digitalization of the economy" and "digital transformations" in government (Leheza et al., 2018).

In order to implement the guarantees of taxpayers, it is necessary to develop a separate electronic system (interactive service). Conventionally it can be called "Choice of alternative taxation system" module. With its help, taxpayers will be able to choose their optimal taxation system based on their own parameters without contacting the specialists and get confirmation of their optimal choice.

3. Special territorial profiles of taxation and guarantees of their participants. Special territorial and economic entities called Special (free) Economic Zones (SEZ) and Priority Development Territories (PDT) are leaders of international economic exchange of capital and goods, catalysts for innovation and points of social and economic development. For positive zoning results the host country must take into account both the general developmental patterns of SEZ and PDT, and their specific features, adapt the mechanism of special territorial and economic entities to its own economy. As a rule, SEZs provide for a whole set of privileges which gave an opportunity to quickly open factories and conduct business activities, the abuse of this process ultimately led to their elimination. Officially, the goal of the SEZ and PDT has not been achieved: in the conditions of social and political changes caused by events of 2004, they were assessed as "tax havens" inside the country. In this regard, in 2005 the government decided to liquidate FEZ (SEZ) and PDT on the territory of Ukraine (Leheza et al., 2020).

The legislation requires a number of amendments, and namely: it is necessary to determine the term of the special economic regime, general management bodies created in all special (free) economic zones and their powers, as well as to specify definite benefits (privileges) provided to economic entities depending on the type of the respective special economic zone and conditions of privileged regimes.

In this case, it is possible to ensure solution of problems of SEZ activity, without losing the investment attractiveness of the country's territories (Leheza et al., 2021). 


\section{Conclusion}

Legal guarantees within tax legal relations are the sectoral embodiment of the system of constitutional guarantees of human rights and freedoms. Legal guarantees within tax legal relations are the embodiment of constitutional and legal guarantees of human and civil rights and at the same time they act as an integrated intersectoral tool, which covers the administrative sphere as well as financial and tax spheres. The object of guarantees is presented as public relations related to protection of human rights, satisfaction of proprietary and non-proprietary interests of taxpayers. Guarantees within tax legal relations should be understood as satisfaction of the proprietary interest of taxpayer or declarant, if we mean tax guarantees in the broadest format, including the relationships of customs regulation. Important challenges of today in the sphere of practical implementation of guarantees in tax legal relations of Ukraine include three interrelated elements.

It is about the widespread use of international practice to guarantee taxpayers' choice of alternative ways of taxing their income, challenges of special territorial tax profiles and guarantees for their participants, the widespread use of "electronic legal relations" in tax administration (in Ukraine it is better known as "digitalization"). In order to implement the potential of guaranteeing taxpayers' choice of alternative methods of taxation it is necessary to create conditions for business entity's performing appropriate calculations and making appropriate decisions. Entrepreneurs should be helped in this by various electronic services. In order to implement the guarantees of taxpayers, it is necessary to develop a separate electronic system (interactive service).

Conventionally it can be called "Choice of alternative taxation system" module. With its help, taxpayers will be able to choose their optimal taxation system based on their own parameters without contacting the specialists and get confirmation of their optimal choice. Another important guarantee of taxpayers' rightsis the restoration of special (free) economic zones as part of the power decentralization program in Ukraine, when the development interests of separate territorial communities provoke creation of special (free) economic zones for implementation of projects in these territories.

\section{Bibliographic References}

ANISTRATENKO, Julia Igorevna. 2017. Legal regulation of small and medium business taxation in Ukraine. On the rights of the manuscript. The dissertation on competition of a scientific degree of the doctor of legal sciences on a specialty 12.00 .07 - administrative law and process; finance law; information law. University of the State Fiscal Service of Ukraine. Irpen, Ukraine. 
GEGHA, Yuriy. 2003. Fundamentals of tax law: a textbook. TV «Knowledge», COO. Kyiv, Ukraine.

HALABURDA, Nadiia; LEHEZA, Yevhen; CHALAVAN, Viktor; YEFIMOV, Volodymyr; YEFIMOVA, Inna. 2021. "Compliance with the principle of the rule of law in guarantees of ensuring the legality of providing public services in Ukraine" In: Journal of law and political sciences. Vol. 29, No. 4, pp. 100-121.

KORNUKOV, Vladimir Mikhailovich. 1988. Theoretical and legal bases of position of the person in criminal proceedings: diss. ... Dr. Jurid. Science: special. 12.00.09. Kyiv, Ukraine.

KUCHERYAVENKO, Mykola Petrovich. 1998. "The concept of a complex institution of tax law" In: Bulletin of the Academy of Legal Sciences of Ukraine. No. 4, pp. 14-36.

LAW OF UKRAINE. 2010. Tax Code of Ukraine № 129-IX. Information of the Verkhovna Rada of Ukraine. Available online. In: https://zakon.rada. gov.ua/laws/show/2755-17. Consultation date: 03/12/2020.

LEHEZA, Yevhen; DELIYA, Yuriy; RYZHKOV, Eduard; ALBUL, Serhiï; SHAMARA, Oleksandr. 2021. "Legal Regulation of the Status of Subjects of Special Competence in Relation to Public Administration in the Sphere of Intellectual Property in Ukraine" In: Jurnal cita hukum indonesian law journal. Vol 9, No 2, pp. 221-236.

LEHEZA, Yevhen; FILIPENKO, Tatiana; SOKOLENKO, Olha; DARAHAN, Valerii; KUCHERENKO, Oleksii. 2020. "Ensuring human rights in ukraine: problematic issues and ways of their solution in the social and legal sphere" In: Cuestiones políticas. Vol. 37, No. 64, pp. 123-136.

LEHEZA, Yevhen; SAVIELIEVA, Maryna; DZHAFAROVA, Olena. 2018. «Structural and legal analysis of scientific activity regulation in developed countries» In: Baltic Journal of Economic Studies. Vol. 4, No. 3, pp. 147157.

POGORILKO Victor Fedorovich. 2006.Constitutional law of Ukraine: textbook. Scientific opinion; Precedent. Kiev, Ukraine.

SHEMSHUCHENKO, Yuriy Sergeevich. 1998. Legal encyclopedia: in 6 vols. K. Publishing house «Ukrainian encyclopedia» named after MP Bazhan. Vol. 1: AG. Kiev, Ukraine.

SKAKUN, Olga Fyodorovna. 2006. Theory of State and Law: a textbook. Konsum, Germany. 
Yevhen Leheza, Andrii Novytskyi, Alina Kravziuk, Nataliia Repekha y Artem Yefremov

SLATVINSKA, Marina Alexandrovna. 2012. Alternative systems of small business taxation: state, problems, prospects: monograph. ONEU. Odessa, Ukraine.

TATSIY, Vasil Yakovlevich; POGORILKO, Victor Fedorovich; TODIKI, Yuriy Mykolayovych. 1999. Constitutional law of Ukraine. Ukrainian Center for Legal Studies.

YUZEFIR, Anatoly. 2018. "Constitutional guarantees for ensuring human and civil rights and freedoms" In: Comparative analytical law. 2018. No. 1, pp. 74-77. 
Vol. 39 N $^{\circ} 71$

Esta revista fue editada en formato digital y publicada en diciembre de 2021, por el Fondo Editorial Serbiluz, Universidad del Zulia. Maracaibo-Venezuela 